\title{
THE EFFECT OF THE ADDITION OF SELECTED PHENOLIC ACIDS ON THE RHEOLOGICAL PROPERTIES OF HEATED SOLUTIONS OF WHEY PROTEINS
}

\author{
D. SZWAJGIER ${ }^{\mathrm{a}, *}$ and W. GuSTAW ${ }^{\mathrm{b}}$ \\ ${ }^{\text {a }}$ Department of Biotechnology, Human Nutrition and Food Commodity Science, \\ ${ }^{\mathrm{b}}$ Department of Fruit, Vegetable and Mushroom Technology, \\ University of Life Sciences, Skromna 8, 20-704 Lublin, Poland
}

(Received: 15 January 2013; accepted: 4 June 2013)

\begin{abstract}
This study measured the flow behaviour of whey protein isolate mixtures with cinnamic or ferulic acids. Samples were heated in a vacuum $\left(80^{\circ} \mathrm{C},-0.9\right.$ atm, 280 r.p.m., 0.5 h). The flow curves of all samples showed a nonNewtonian shear thinning flow and the viscoelastic properties were typical for weak gel systems. At $\mathrm{pH}$ 6.0, 6.7, and 8.0 , the highest shear stress values were obtained with 20,40 , and $40 \mathrm{mg}$ of cinnamic acid $\mathrm{g}^{-1}$ protein, respectively. At $\mathrm{pH}$ 6.0, the use of ferulic acid (20 $\mathrm{mg} \mathrm{g}^{-1}$ protein) resulted in the elevation of shear stress values, but at $\mathrm{pH} 8.0$, ferulic acid caused a decrease in shear stress values in comparison to cinnamic acid. The thixotropic area $\left(\mathrm{A}_{T}\right)$ was increased in mixtures containing 20-40 mg cinnamic acid $\mathrm{g}^{-1}$ protein (at $\mathrm{pH}$ 6.7) and $20 \mathrm{mg}$ of cinnamic acid $\mathrm{g}^{-1}$ protein (at $\mathrm{pH}$ 6.0). Similarly, the addition of ferulic acid (40 and $20 \mathrm{mg} \mathrm{g}^{-1}$ protein at $\mathrm{pH} 6.7$ and 6.0, respectively) caused a significant increase in $\mathrm{A}_{\mathrm{T}}$. At $\mathrm{pH}$ 8.0, no significant differences in $\mathrm{A}_{\mathrm{T}}$ values were observed between samples. Such systems can be applied with reference to health promoting foods such as WPI-based desserts.

Keywords: whey protein isolate, cinnamic acid, ferulic acid, flow behaviour, rheological properties
\end{abstract}

Phenolic acids exerted strong in vitro (e.g. SzWAJgIER, 2009), in vivo (e.g. Young et al., 2008) antioxidant activity as well as anticancer activity as it was lately thoroughly reviewed by DE and co-workers (2011). A considerable number of various positive physiological functions of phenolic acids were significantly improved in patients as well as in experimental animals (e.g. Duchnowicz et al., 2011). The neuroprotection of phenolic acids in the central nervous system of experimental animals has been observed in numerous experiments (e.g. CHENG et al., 2008). It has been previously noted that phenolic acids can interact with proteins, especially those rich in proline, via hydrophobic or hydrogen bonding (HASLAM \& LiLLEY, 1988). The formation of edible films composed of cross-links between ferulic acid or caffeic acid and porcine plasma protein (NUTHONG et al., 2009) was observed. The protein coagulation pattern (during the production of cheese curds) is modified by the addition of homovanillic and tannic acids; moreover, the $\mathrm{pH}$ value of the cheese is significantly reduced, while the gel formation rate is increased (HAN et al., 2011a). The curd moisture content decreases and the firmness and texture are not affected by the addition of polyphenolic compounds (tannic and homovanillic acids and various flavonoids) to cheese products (HAN et al., 2011b). Glycosylated gallic acid pentamer binds very effectively to caseins in milk desserts and, less potently, to blood serum albumins (LUCK et al., 1994). Ferulic acid and caffeic acid effectively increase the heat stability of skimmed milk and concentrated skimmed milk heated at $140^{\circ} \mathrm{C}$ (O’CONNEL \& Fox, 1999).

\footnotetext{
* To whom correspondence should be addressed. Phone/Fax: +4881 4623353; e-mail: dszwajgier@hotmail.com
} 
The aim of this work was to introduce ferulic acid and its precursor cinnamic acid into mixtures based on whey protein isolate (WPI). Selected rheological properties were measured in order to determine optimal conditions for the production of these mixtures.

\section{Materials and methods}

\subsection{Materials}

Whey protein isolate (WPI, protein content 91.7\%) was purchased from Milei GmbH, Leutkirch, Germany. Cinnamic acid (Cat. no. C80857) and ferulic acid (Cat. no. 128708) were purchased from Sigma-Aldrich, Poznań, Poland. Other reagents were of analytical grade and were purchased from POCH (Gliwice, Poland).

\subsection{Preparation of test solutions}

Test solutions were obtained by mixing $6 \mathrm{~g}$ of WPI with distilled water up to $100 \mathrm{~cm}^{3}$ using a magnetic stirrer $(0.5 \mathrm{~h}$, room temperature). Phenolic acids were added to the WPI solution at 20,30 , or $40 \mathrm{mg} \mathrm{g}^{-1}$ protein followed by adjustment of $\mathrm{pH}$ by $2 \mathrm{~mol} \mathrm{dm}{ }^{-3} \mathrm{NaOH}$ or $\mathrm{HCl}$ solution. Test solutions were heated in a rotary evaporator (Rotavapor, Büchi, Switzerland; $80{ }^{\circ} \mathrm{C}$, vacuum 0.9 atm, 280 r.p.m.).

\subsection{Rheological properties}

The rheological properties were performed at $20{ }^{\circ} \mathrm{C}$ using a dynamic rheometer RS 300 (ThermoHaake, Karlsruhe, Germany) with a Z41 coaxial cylinder system. Flow curves were measured by recording shear stress values when shearing the samples at an increasing shear rate from 0 to $300 \mathrm{~s}^{-1}$ for a period of $60 \mathrm{~s}$ and in reverse sequence for the same time in the case of thixotropic measurements. The thixotropic area $\left(\mathrm{A}_{\mathrm{T}}\right)$ was determined using Rheowin Pro software (v. 3.61, Haake) as the area limited between the up-curve and the down-curve. Experimental data of descending flow curves were matched to the Ostwald de Waele model equation using Rheowin Pro software (v. 3.61, Haake):

$$
\sigma=\mathrm{K} \gamma^{\mathrm{n}}
$$

where $\sigma=$ shear stress, $\mathrm{K}=$ consistency index, $\gamma=$ shear rate, $\mathrm{n}=$ flow behaviour index

Tukey's HSD test (STATISTICA 8.0, StatSoft, Inc., USA) was used for the determination of statistical differences with the significance denoted at $\mathrm{P}<0.05$.

\section{Results and discussion}

The flow curves of all samples showed a non-Newtonian shear thinning flow (Figs 1-3). The observed type of rheological behaviour was in accordance with that previously reported in various milk products containing whey proteins (e.g. MLEKo \& Gustaw, 2002; Gustaw et al., 2006). The highest shear stress values in WPI suspensions containing cinnamic acid (Figs 1-3) were obtained at $\mathrm{pH} 6.0$ and in the presence of $20 \mathrm{mg}$ cinnamic acid $\mathrm{g}^{-1}$ protein (Fig. 2A). However, at pH 6.7 (native $\mathrm{pH}$ ) and 8.0 (Figs 1A and 3A, respectively), the highest shear stress values were obtained (in the decreasing order: $6.7>8.0$ ) with $40 \mathrm{mg}$ cinnamic acid $\mathrm{g}^{-1}$ 
protein. The shapes of the flow curves of whey protein mixtures with cinnamic acid obtained at pH 6.7, 8.0 (Figs 1A, 3A), and pH 6.0 (Fig. 2A) were similar to Newtonian and pseudoplastic fluids, respectively. The introduction of ferulic acid instead of cinnamic acid $\left(40 \mathrm{mg} \mathrm{g}^{-1}\right.$ protein, Fig. 1A versus 1B) caused no substantial changes in the maximal shear stress values observed at $\mathrm{pH}$ 6.7. However, at $\mathrm{pH} 6.0$ the replacement of cinnamic acid by ferulic acid resulted in increased shear stress values (Figs $2 \mathrm{~A}$ and $2 \mathrm{~B}$ ). It is noteworthy that at $\mathrm{pH} 6.0$ the highest shear stress values were measured in samples that contained only $20 \mathrm{mg}$ phenolic acid $\mathrm{g}^{-1}$ protein. At $\mathrm{pH} 8.0$, the addition of ferulic acid caused a decrease in shear stress values in comparison to mixtures with cinnamic acid (Fig. 3A versus 3B). The flow curves obtained using whey protein-ferulic acid suspensions at $\mathrm{pH} 6.7$ and $\mathrm{pH} 8.0$ (Figs 1 and 3, respectively) were, in shape, similar to Newtonian fluids. Only in the case of the mixture containing $40 \mathrm{mg}$ ferulic acid $\mathrm{g}^{-1}$ protein was the flow curve typical for pseudoplastic fluid. Also, at $\mathrm{pH} 6.0 \mathrm{a}$ flow behaviour similar to pseudoplastic fluids was observed in the case of all mixtures containing ferulic acid, except the suspension containing $20 \mathrm{mg}$ ferulic acid $\mathrm{g}^{-1}$ protein (Fig. 2B).
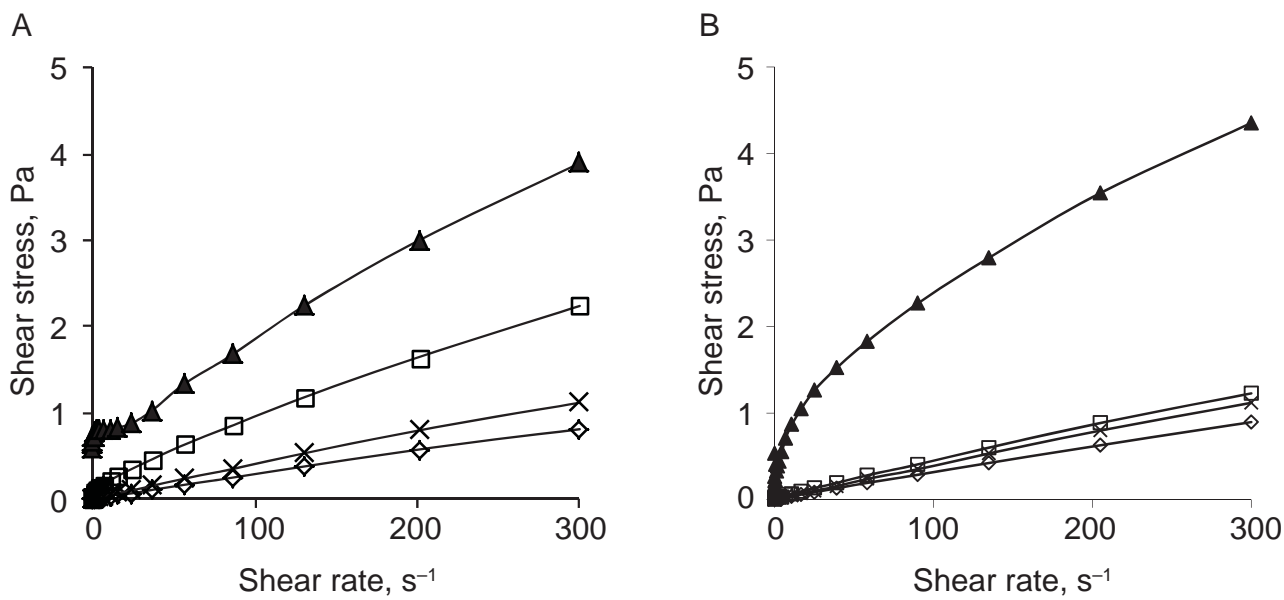

Fig. 1. Flow curves of WPI solutions containing cinnamic (A) and ferulic acid (B) (pH 6.7) $\diamond: 0 \mathrm{mg} \mathrm{g}^{-1}$ protein; $\times: 20 \mathrm{mg} \mathrm{g}^{-1}$ protein; $\square: 30 \mathrm{mg} \mathrm{g}^{-1}$ protein; $\boldsymbol{\Delta}: 40 \mathrm{mg} \mathrm{g}^{-1}$ protein

At given $\mathrm{pH}$, the addition of cinnamic acid (20,30, or $40 \mathrm{mg} \mathrm{g}^{-1}$ protein, Table 1) had generally no influence on the consistency index $(\mathrm{K})$ of mixtures, in comparison to samples without this phenolic acid. The only exception was the mixture prepared at $\mathrm{pH} 6.0$ with the use of $20 \mathrm{mg}$ cinnamic acid $\mathrm{g}^{-1}$ protein (significantly higher $\mathrm{K}$ value in comparison to other samples at this $\mathrm{pH})$. Similarly, at given $\mathrm{pH}$, the addition of ferulic acid $\left(20,30\right.$, or $40 \mathrm{mg} \mathrm{g}^{-1}$ protein, Table 2) had generally no influence on the consistency index (K) of mixtures, in comparison to samples without this phenolic acid. However, in this case, more exceptions were observed: the $\mathrm{K}$ value of samples containing $40 \mathrm{mg}$ (at pH 6.7) or $20 \mathrm{mg}$ of ferulic acid $\mathrm{g}^{-1}$ protein (at $\mathrm{pH} 6.0$ and 8.0 ) were significantly higher than $\mathrm{K}$ values of other mixtures at corresponding $\mathrm{pH}$. The consistency index $\mathrm{K}$ is positively correlated with the viscosity as well as with the shear stress values of the suspensions (ANTON et al., 2001). Indeed, this correlation with the $\mathrm{K}$ index and the shear stress values was observed in the case of the selected samples (Tables 1 and 2). 
A

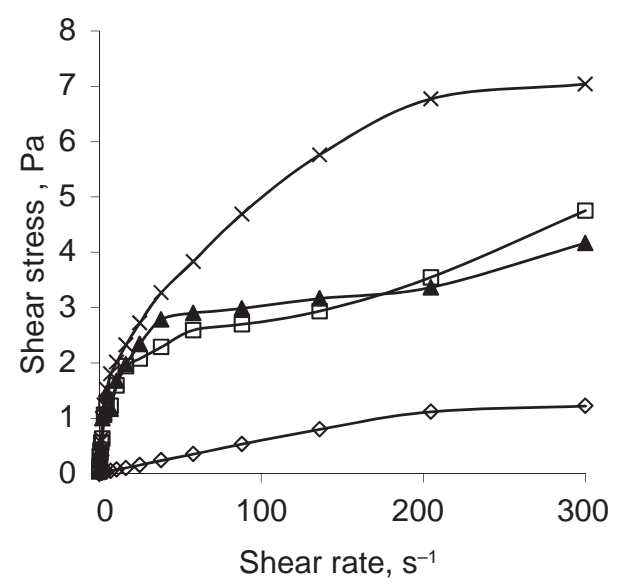

B

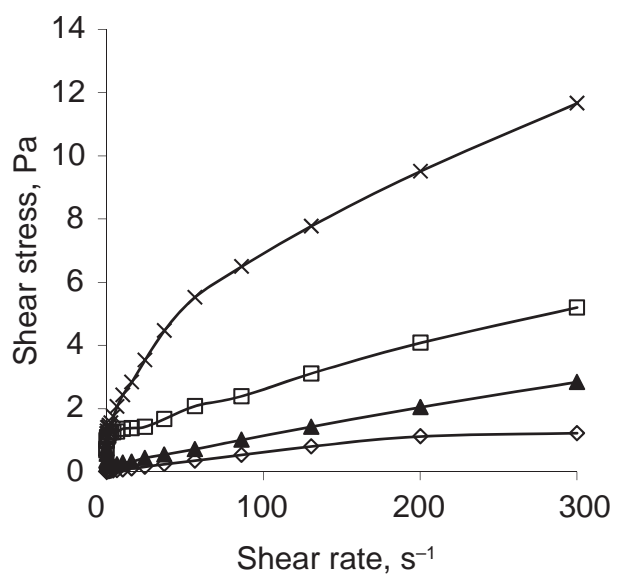

Fig. 2. Flow curves of WPI solutions containing cinnamic (A) and ferulic acid (B) (pH 6.0) $\diamond: 0 \mathrm{mg} \mathrm{g}^{-1}$ protein; $\times: 20 \mathrm{mg} \mathrm{g}^{-1}$ protein; $\square: 30 \mathrm{mg} \mathrm{g}^{-1}$ protein; $\boldsymbol{\Delta}: 40 \mathrm{mg} \mathrm{g}^{-1}$ protein

A

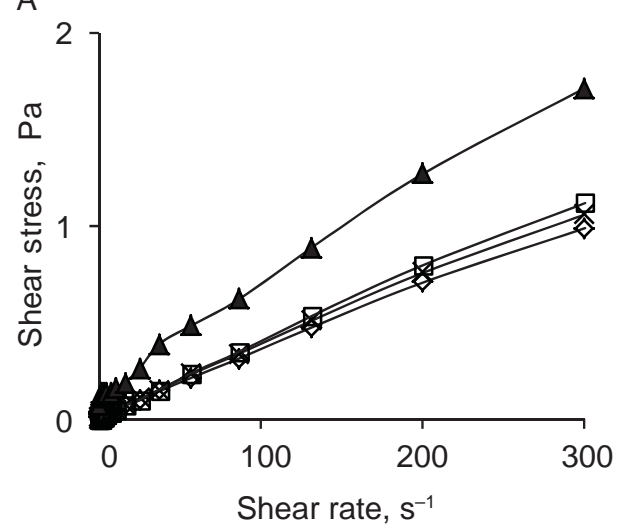

B

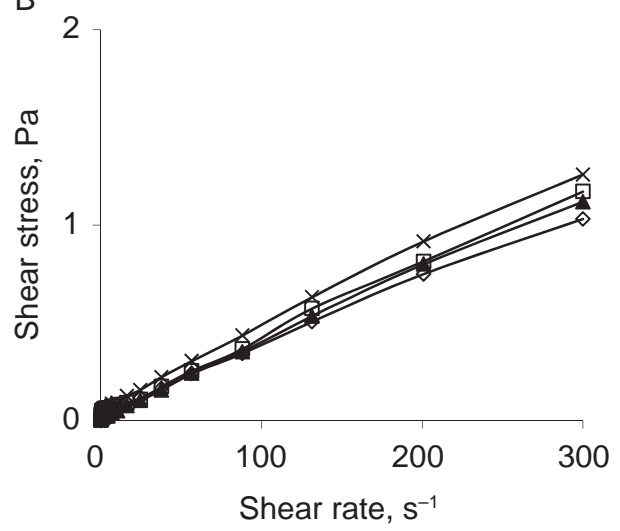

Fig. 3. Flow curves of WPI solutions containing cinnamic (A) and ferulic acid (B) ( $\mathrm{pH} 8.0)$

$\diamond: 0 \mathrm{mg} \mathrm{g}^{-1}$ protein; $\times: 20 \mathrm{mg} \mathrm{g}^{-1}$ protein; $\square: 30 \mathrm{mg} \mathrm{g}^{-1}$ protein; $\boldsymbol{\Lambda}: 40 \mathrm{mg} \mathrm{g}^{-1}$ protein

The flow index $n$ was significantly higher in the case of either mixtures prepared using $40 \mathrm{mg}$ cinnamic acid $\mathrm{g}^{-1}$ protein at $\mathrm{pH} 6.0$, or in the absence of this acid. This result is, however, hard to elucidate and another test should be undertaken in order to verify it. Finally, the differences in the $n$ value were not significant $(\mathrm{P}>0.05)$ within the samples prepared with the use of 0-40 $\mathrm{mg}$ cinnamic or ferulic acid $\mathrm{g}^{-1}$ protein (Tables 1 and 2).

The thixotropic area $\left(\mathrm{A}_{\mathrm{T}}\right)$ was considerably increased in mixtures containing $20-40 \mathrm{mg}$ cinnamic acid $\mathrm{g}^{-1}$ protein at $\mathrm{pH} 6.7$ and $20 \mathrm{mg}$ cinnamic acid $\mathrm{g}^{-1}$ protein at $\mathrm{pH} 6.0$ (Table 1). Similarly, the addition of ferulic acid ( 40 and $20 \mathrm{mg} \mathrm{g}^{-1}$ protein at $\mathrm{pH} 6.7$ and 6.0 , respectively) to suspensions caused a significant $(\mathrm{P}<0.05)$ increase in $\mathrm{A}_{\mathrm{T}}$ (Table 2). At $\mathrm{pH} 8.0$, no significant differences in $A_{T}$ values were observed between the samples (Tables 1 and 2). The comparison of two matching samples (that contained either cinnamic or ferulic acid) showed that at $\mathrm{pH} 6.7$ the consistency index $(\mathrm{K})$ of the sample containing ferulic acid was 


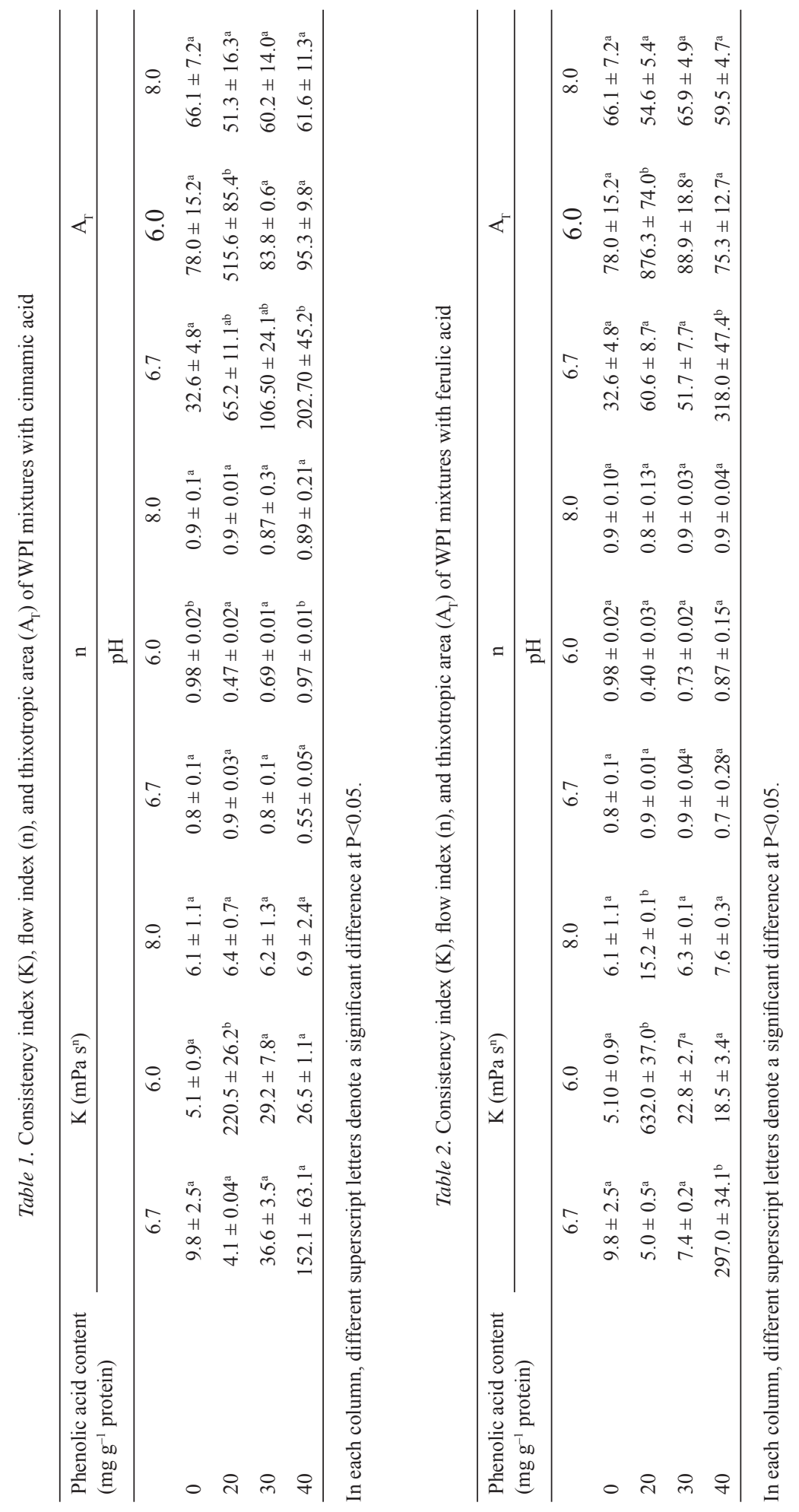


higher than that of the corresponding sample with cinnamic acid (40 mg phenolic acid $\mathrm{g}^{-1}$ protein, Tables 1 and 2). At $\mathrm{pH} 6.0$, the consistency index $(\mathrm{K})$ and the thixotropic area $\left(\mathrm{A}_{\mathrm{T}}\right)$ of the sample containing ferulic acid were higher than that of the corresponding sample with the other acid (at $20 \mathrm{mg}$ phenolic acid $\mathrm{g}^{-1}$ protein). No statistically significant differences in matching samples produced at $\mathrm{pH} 8.0$ were seen in this study.

At ambient temperature and neutral $\mathrm{pH}$, the main whey protein $\beta$-lactoglobulin is present predominantly in the form of a non-covalent dimer. The increase of temperature causes a reversible unfolding of the monomer followed by an irreversible aggregation. Association between these aggregates forms larger aggregates with different characteristics depending on the heat treatment and $\mathrm{pH}$ values (HofFMAnN \& van MiL, 1999). The increased size of aggregates induces the increased particles volume fraction resulting in a more viscous solution (VARDHANABHUti \& Foegeding, 1999). However, the size of aggregates depends on pH. BAUER and co-workers (2000) observed modified small oligomers (ranging from dimers to tetramers) formed at $\mathrm{pH}$ 8.7. This could explain the low viscosity systems obtained at $\mathrm{pH}$ 8.0.

The addition of cinnamic or ferulic acid to whey protein suspension improved a number of rheological properties of test mixtures. Previously, BARTOLOME and co-workers (2000) observed the binding of protocatechuic, caffeic, $p$-coumaric and $p$-hydroxybenzoic acids to bovine serum albumin. The formation of soy trypsin inhibitor complexes with caffeic, chlorogenic, and gallic acids was seen (RAwel et al., 2002). Hiller and Lorenzen (2011) obtained the highest degree of whey protein modification with chlorogenic acid. An increase in the cooperative diffusive coefficients of gelatine gels by caffeic, chlorogenic, and ferulic acids and an increase in the rigidity of gelatine-based microparticular coacervates by caffeic acid was also observed (STRAuSS \& GiBSON, 2004). RAwEL and co-workers (2001) detected a decreased solubility of whey proteins at $\mathrm{pH} 4.0-5.0$ and in the presence of chlorogenic, caffeic, and gallic acids. In order to identify the primary cause of herein presented results, the analysis of hydrophilic and/or hydrophobic interactions between molecules in focus is indispensable, taking under consideration the effect of $\mathrm{pH}$. RAWEL and co-workers (2001) strongly underlined that the strength of the complexation depends on the $\mathrm{pH}$ of the solution. PRASAD (1988) has suggested that the hydrogen interactions between phenolic acids and proteins are unusually strong. At lower $\mathrm{pH}$, phenolic acids form hydrogen or hydrophobic interactions rather than ionic ones (a lower degree of ionization). Therefore, a predominant role of the hydrophobic phenyl ring with affinity to hydrophobic side chains of amino-acid residues can be indicated. Indeed, our results confirm these observations. At $\mathrm{pH}$ 6.0, the shear stress values of mixtures containing $20 \mathrm{mg}$ ferulic acid g-1 protein were higher than the corresponding results obtained with cinnamic acid. This result suggests the additional role of hydrogen interactions caused by the presence of hydroxyl group and/or the hydrophobic interactions caused by the presence of methoxyl group in ferulic acid. Nonetheless, the formation covalent bonds in our mixtures cannot be completely excluded. The simultaneous presence of different types of interactions leading to the association of a phenolic acid with a protein molecule has been repeatedly demonstrated by numerous authors - as essentially reviewed by RAWEL and ROHN (2010).

\section{Conclusions}

It can be concluded that the addition of cinnamic or ferulic acid to suspensions of whey proteins caused an improvement of the rheological properties of the test mixtures. An increase in shear stress values and the consistency index was observed. These results can be used for the invention of new WPI-based desserts enriched with beneficial, low molecular antioxidant phenolic acids. 


\section{References}

Anton, M., Chapleau, N., Beaumal, V., Delepine, S. \& De Lamballerie-Anton, M. (2001): Effect of high-pressure treatment on rheology of oil-in-water emulsions prepared with hen egg yolk. Innov. Fd Sci. Emerg. Technol., 2, 9-21.

Bartolome, B., Estrella, I. \& Hernandez, M.T. (2000): Interaction of low molecular weight phenolics with proteins (BSA). J. Fd Sci., 65, 617-621.

Bauer, R., Carrotta, R., Rischel, C. \& Øgendal, L. (2000): Characterization and isolation of intermediates in $\beta$-lactoglobulin heat aggregation at high pH. Biophys. J., 79, 1030-1038.

Cheng, C.Y., Su, S.Y., TAng, N.Y., Ho, T.Y., Chiang, S.Y. \& Hsieh, C.L. (2008): Ferulic acid provides neuroprotection against oxidative stress-related apoptosis after cerebral ischemia/reperfusion injury by inhibiting of ICAM-1 mRNA expression in rats. Brain Res., 13, 136-150.

De, P., Baltas M. \& Bedos-Belval, F. (2011): Cinnamic acid derivatives as anticancer agents - A review. Curr. Med. Chem., 18, 1672-1703.

Duchnowicz, P., Broncel, M., Podsędek, A. \& Koter-Michalak, M. (2011): Hypolipidemic and antioxidant effects of hydroxycinnamic acids, quercetin, and cyanidin 3-glucoside in hypercholesterolemic erythrocytes (in vitro study). Eur. J. Nutr., 51, 435-443.

Gustaw, W., Glibowski, P. \& Mleko, S. (2006): The rheological properties of yoghurt with incorporated whey protein aggregates/polymers. Milchwissenschaft, 61, 415-419.

Han, J., Britten, M., St-Gelais, D., Champagne, C.P., Fustier P., Salmieri, S. \& Lacroix, M. (2011a): Polyphenolic compounds as functional ingredients in cheese. Fd Chem., 124, 1589-1594.

Han, J., Britten, M., St-Gelais, D., Champagne, C.P., Fustier, P., Salmieri, S. \& Lacroix, M. (2011в): Effect of polyphenolic ingredients on physical characteristics of cheese. Fd Res. Int., 44, 494-497.

Haslam, E. \& Lilley, T.H. (1988): Natural astringency in foodstuffs. A molecular interpretation. Crit. Rev. Fd Sci. Nutr., 27, 1-40.

Hiller, B. \& Lorenzen, P.C. (2011): Optimization of enzymatic oligomerization reaction conditions for free milk protein products via ceteris-paribus approach. Fd Res. Int., 44, 3118-3122.

Hoffmann, M.A.M. \& van MiL, P.J.J.M. (1999): Heat-induced aggregation of beta-lactoglobulin as a function of $\mathrm{pH}$. J. Agric. Fd Chem., 47, 1898-1905.

Luck, G., Liao, H., Murray, N.J., Grimmer, H.R., Warminski, E.E., Williamson, M.P., Lilley, T.H. \& Haslam, E. (1994): Polyphenols, astringency and proline-rich proteins. Phytochemistry, 37, 357-371.

Mleko, S. \& Gustaw, W. (2002): Rheological changes due to substitution of total milk proteins by whey proteins in dairy desserts. J. Fd Sci. Technol., 39, 170-172.

Nuthong, P., Benjakul, S. \& Prodpran, T. (2009): Effect of phenolic compounds on the properties of porcine plasma protein-based film. Fd Hydrocoll., 23, 736-741.

O'Connel, J.E. \& Fox, P.F. (1999): Effect of phenolic compounds on the heat stability of milk and concentrated milk. J. Dairy Res., 66, 399-407.

Prasad, D.T. (1988): Studies on the interaction of sunflower albumins with chlorogenic acid. J. Agric. Fd Chem. 36 , $450-452$.

Rawel, H.M., Czajka, D., Rohn, S. \& Kroll, J. (2002): Interactions of different phenolic acids and flavonoids with soy proteins. Int. J. Biol. Macromol., 30, 137-150.

Rawel, H.M., Kroll, J. \& Hohl, U.C. (2001): Model studies on reactions of plant phenols with whey proteins. Nahrung/Fd, 45, 72-81.

Rawel, H.M. \& Rohn, S. (2010): Nature of hydroxycinnamate-protein interactions. Phytochem. Rev., 9, 93-109.

Strauss, G. \& Gibson, S.M. (2004): Plant phenolics as cross-linkers of gelatin gels and gelatin-based coacervates for use as food ingredients. Fd Hydrocoll., 18, 81-89.

SzwaJgier, D. (2009): Content of individual phenolic acids in worts and beers and their possible contribution to the antiradical activity of beer. J. Inst. Brew., 115, 243-252.

Vardhanabhuti, B. \& Foegeding, E.A. (1999): Rheological properties and characterization of polymerized whey protein isolates. J. Agric. Fd Chem., 47, 3649-3655.

Young, J., Wahle, K.W. \& Boyle, S.P. (2008): Cytoprotective effects of phenolic antioxidants and essential fatty acids in human blood monocyte and neuroblastoma cell lines: Surrogates for neurological damage in vivo. Prostaglandins Leukot. Ess., 78, 145-159. 